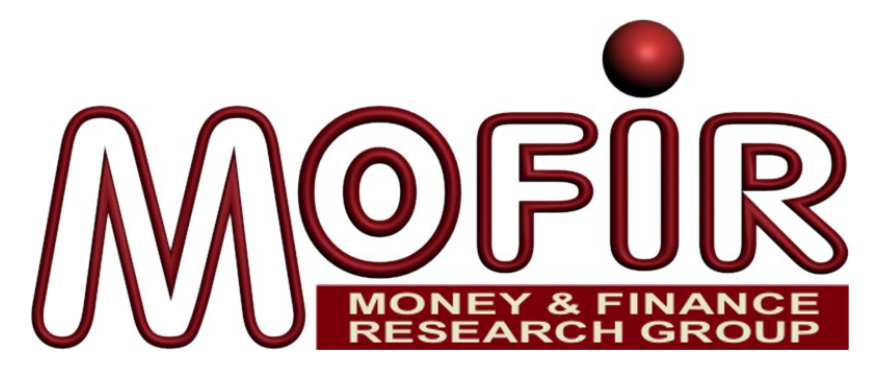

\title{
The 2008-2009 Financial Crisis AND the HIPCs: Another Debt CRisis?
}

\author{
Andrea F. Presbitero \\ Università Politecnica delle Marche, Department of Economics \\ MoFiR \\ CeMaFiR
}

MoFiR working paper $\mathrm{n}^{\circ} 29$

September 2009 


\title{
The 2008-2009 Financial Crisis and the HIPCs: Another Debt Crisis?
}

\author{
Andrea F. Presbitero ${ }^{\S}$ \\ Università Politecnica delle Marche - Dipartimento di Economia \\ MoFiR (Money and Finance Research group)
}

\section{September 2009}

\section{Introduction}

The current debt crisis in the Heavily Indebted and Poor Countries (HIPC) is a long lasting phenomenon that hindered economic growth due to increasing bilateral loans and concessional lending, lack of macroeconomic adjustments and structural reforms in poor countries, and a number of exogenous domestic and international shocks. As a result of this adverse scenario, these countries started accumulating external debt reaching extreme ratios of debt to GDP and exports in the nineties (Figure 1.1).

At the beginning of the seventies HIPCs had, on average, a level of external debt equal to total exports and to around a fourth of gross domestic product. By the end of the eighties, the stock of debt became equal to the annual GDP and to more than five times exports, notwithstanding the extensive use of nonconcessional flow reschedulings granted by the informal group of sovereign bilateral creditor (Paris Club). The increasing external debt was seen as unsustainable and determined a number of debt relief initiatives that were introduced during the late 1980s and the 1990s (Toronto, London, Naples and Lyon terms), according to which bilateral donors agreed to rescheduling on concessional terms and introducing the option of stock-of-debt cancellation (see Daseking and Powell, 1999, for a detailed discussion of the history of debt relief).

By contrast, multilateral development banks and the International Monetary Fund (IMF) resisted

$\S$ I wish to thank Marco Arnone for the useful discussions on debt relief and the participants to the XI meeting of the "Associazione degli Economisti di Lingua Neolatina" (San Benedetto, Italy). The usual disclaimers apply. 
recommendations to provide debt relief on their concessional loans and maintained their status of preferred creditors, according to which payments of multilateral debt takes priority over private and bilateral debt. In those years, the stock of external debt kept growing and, at its peak, the level of external debt in the whole sample of HIPCs reached 152 percent of GDP (in 1994) and 663 percent of exports (in 1993). As a result, Non Government Organizations (NGOs) and some sovereign lenders (notably, the UK, the Netherlands and Scandinavian countries) put growing pressures on multilateral institutions and western donors to increase debt relief efforts and extend debt reduction to multilateral loans.

Figure 1.1: External Debt in HIPCs

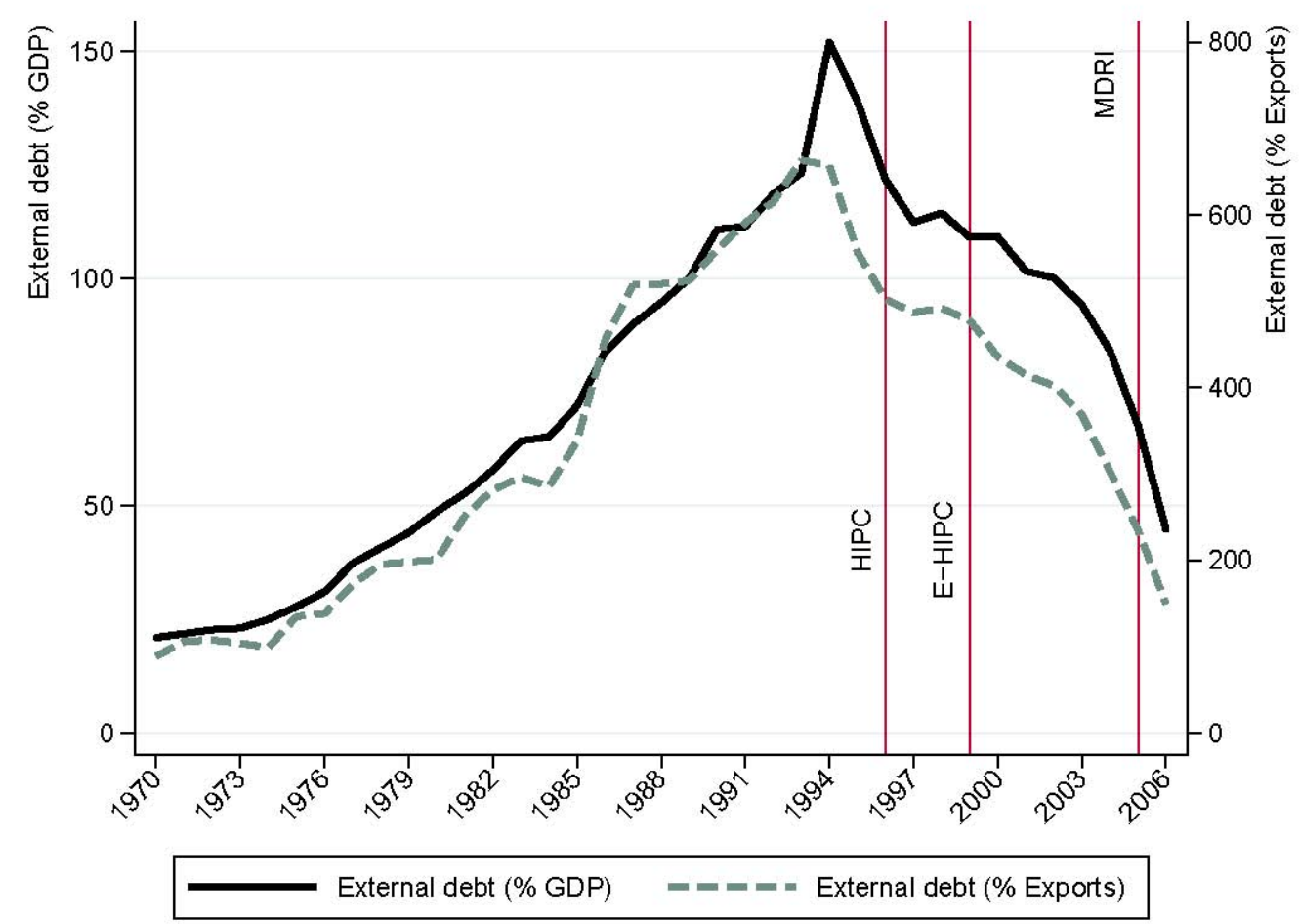

Source: World Development Indicators 2008 (World Bank. 2008)

The IMF and the World Bank (WB) were initially reluctant arguing that debt relief was not necessary neither affordable and that it could generate moral hazard and undermine IMF conditionality (Evans, 1999; Teunissen, 2004). Nevertheless, under increasing political pressure from their major shareholders, in 1996 the 'sister institutions' endorsed the debt relief policy and launched the Heavily Indebted Poor Country Initiative, which was enhanced in 1999 in order to provide faster debt relief to a 
larger number of countries. Finally, in 2005, donors pledged to cancel the whole debt held by the International Development Association of the WB, the IMF and the African Development Fund of the countries that have reached the completion point under the Enhanced Heavily Indebted Poor Countries Initiative (in December 2006 also the Inter-American Development Bank agreed on the 100 percent debt relief). Thanks to these efforts, external debt ratios started declining from their peaks and, especially because of the steep reduction occurred in the last five years, in 2006 the average external debt to GDP ratio reached 45 percent and the ratio over exports declined to 150 percent, the threshold which was identified as the sustainable level of debt under the HIPC Initiative.

The various debt relief initiatives of the last decades were only partially successful in reducing external debt dependence in poor countries, increasing poverty reduction and social expenditures, and putting heavily indebted countries on a debt sustainable path. Results in terms of higher investments and enhanced economic growth are instead less evident (Easterly 2002; Depetris Chauvin and Kraay 2005; Presbitero 2009). In any case, the positive results obtained by the efforts coordinated by the International Financial Institutions cannot be taken for granted and there are many sources of vulnerability, such as rising domestic debt (Arnone and Presbitero 2007) and the predatory role of new lenders and vulture funds lawsuits, which take advantage of the lack of coordination and binding agreements amongst donors and of the borrowing space created by the HIPC Initiative and by the MDRI (Arnone and Presbitero 2008). On the top of that, external exogenous shocks, such ad windfalls in the commodity prices, are always a threat to poverty reduction policies and debt sustainability.

Dealing with one exogenous adverse external shock at a time is generally a difficult challenge for poor countries, because of limited fiscal space, few policy options and scarce debt management capacity. The current financial crisis, because of its unprecedented severity and global scale, forces poor countries to deal with multiple exogenous shocks simultaneously: mitigating the effects of a reduction in trade, capital inflows and foreign assistance is going to be a very hard task and to require a massive intervention by donors and by the International Financial Institutions (IFI), in order to avoid to jeopardize the progresses done so far. In the following, we try to spell out the way in which the global economic-financial crisis has affected and still weighs on Low-Income Countries (LIC), focusing on overall debt sustainability. Section 2 points out the transmission channels of the global financial crisis to LIC; Section 3 discusses the policy options of poor countries and the response by the IFI; Section 4 
assesses the possibility that the current financial turmoil triggers another debt crisis in HIPCs, and Section 5 concludes.

\section{The Channels Through Which the Crisis Affects Low Income Countries}

Although the epicenter of the current turmoil is the financial industry of the richest countries and the recession is hitting harder in Europe and the United States, it is becoming clearer over time that dramatic long-run consequences are likely to be suffered by low income countries. Even if poor countries are not so directly interconnected to the world financial system, so that they can escape the direct contagion channel, they are exposed to many other sources of vulnerability and lack the appropriate resources and instruments to face the crisis ${ }^{1}$. Thus, the impact of the financial turmoil is extremely heterogeneous among poor countries, depending on their economic structure, external dependence and institutional framework (de Velde 2009). Nonetheless, there are different common indirect channels through which the current financial turmoil and the recession in the rich world could affect poor countries (Mold et al. 2009; International Monetary Fund 2009a)².

The most important source of vulnerability is the critical dependence of poor countries on export revenues and their narrow export base, since commodities still account for about 70 percent of LIC exports. Thus, the sharp decline in the world demand following the crisis has dramatic consequences on the volume of exports. Moreover, the fall in commodity prices, that is reversing the upward trend of recent years which helped sustaining Africa's growth rates, has to be taken into account. The most recent IMF projections (International Monetary Fund 2009a) show a sharp fall in exports, from 26.6 to 21.8 percent of GDP and a deterioration in the terms of trade. The fall in the price of copper, in example, is dramatically hurting the economy of Zambia, whose foreign exchange earnings are generated for three quarters by copper mining: some large investment projects are put on hold, poverty

$1 \mathrm{By}$ contrast, the bailout of the financial industry in OECD countries is going to cost a huge amount of public money. Even a tiny percentage of it could have been spent, according to a number of scholars and NGOs, on a number of different aid programs (i.e. the 700 billion dollars program originally proposed to bail out Wall Street is about seven fold the global level of annual official development assistance). See below and section 2 for a discussion about aid flows and fiscal stimulus in poor countries.

2 The speech by Dominique Strauss-Kahn on the impact of the financial crisis on low income countries at the Brookings in March 2009 is particularly instructive (The Brookings Institution 2009). Also, the Overseas Development Institute has a dedicated website (http://www.odi.org.uk/odi-on/financial-crisis/default.asp, last accessed: September 2009), where it collects numerous publications and resources about the effect of the crisis on developing countries. 
rates increase and debt sustainability is at risk (Jubilee Debt Campaign 2009). However, some price movements, such as the decline of the imports bills for fertilizers, food and oil can favor (non-oil producing) low income countries' current account (de Velde 2009). In fact, the World Bank (2009) estimates that between July 2008 and May 2009 the terms of trade deteriorated for 18 African countries, but improved for 26 countries, mainly oil importers.

The second transmission channel is the dependence on external financing and foreign assistance. The world crisis is likely to generate a reduction in capital flows to developing countries: according to the Institute of International Finance, net private capital flows to poor countries will slump from almost USD 1 trillion in 2007 to USD 165 billion in 2009. Even if private capital flows to Africa account for a negligible share of global flows, their decline for African countries is substantial: The World Bank estimates that net private capital inflows to Sub-Saharan African countries contracted by 35 percent in 2008 with respect to 2007, lowering back at USD 36 billion, as in 2005 (World Bank 2009a). Some Low Income African Countries have recently gained access to the international bond market and to the private debt market, but the crisis has dry up this financing channel, delaying the construction of important infrastructures, such as toll roads and gas pipelines. Ghana, in example, accessed syndacated bank loans and issued an oversubscribed USD 750 million Eurobond in September 2007, but had to postpone plans for a $\$ 300$ million issue because of poor global market conditions (Hostland 2009). On the whole, African countries raised in 2007 \$6.5 billion in international bonds, while in 2008 they raised nothing (The Economist 2009) $)^{3}$.

Also foreign direct investments (FDI), which are generally perceived as a better and more stable source of external financing than portfolio and debt flows, are pro-cyclical, as testified by their reduction in 2008 and 2009. UNCTAD (2009) estimates that global FDI halved in the first quarter of 2009, on a year-to-year basis. This reduction interests also inflows to developing countries, where, however, FDI continued to rise in 2008, even if at a slower pace than in previous years. The most recent data of the IMF World Economic Outlook project for 2009 a fall in FDI inflows to LICs of around 20-25 percent with respect to their 2008 level (International Monetary Fund 2009a). Thus a number of countries will have to scale down large infrastructure projects. According to the World Bank, in example, Congo DR

3 Private capital flows could tap the LICs financing gap and bring collateral benefits (Kose et al 2009), but brings risks and are generally not found to have a causal effect on economic growth (Prasad, Rajan and Subramanian 2006). With specific respect to the HIPCs, non concessional borrowing raises concerns on future debt sustainability, see section 4. 
is estimated to loose USD 1.8 billion in foreign direct investments because of the financial crisis.

Furthermore, African countries are highly dependent on bilateral and multilateral aid flows - especially the former ones - which are likely to fall in response to the crisis. During the 1972-3 global recession aid fell by 15 percent before bouncing back quickly. But in 1990-93 aid plummeted by nearly 25 percent in a five-year period, and did not return to its 1992 levels until 2003. Humanitarian aid followed the same pattern. A recent analysis limited to the United States points out that economic and financial conditions worsen aid flows and estimates a potential decline in ODA ranging from 13 to 30 percent depending on the severity of the current crisis (Mendoza et al. 2009). Recent data suggest that some donors, such as Ireland and Italy, are already reducing their disbursements, while others are "front-loading" their aid efforts, meaning that they are borrowing from future years to keep steady now, so that aid could fall further after 2009 (The Economist 2009).

To better gauge the impact of past crisis on foreign assistance to Africa, we replicate the exercise done by Frot (2009) on the whole sample of developing countries, by plotting the evolution of the Official Development Assistance flows to Sub-Saharan African countries by the most important donors which were affected by a crisis during the past fifty years (Figure 2$)^{4}$. The diagrams are instructive in the sense that they can provide a benchmark of how major donors reacted in the past to a (regional) crisis. However, the global nature and the intensity of the current shock is likely to have different, and probably stronger, consequences, as testified by the preliminary IMF projections on aid flows to LICs, which should decline with respect to 2008. In any case, the picture is not encouraging. Finland and Sweden dramatically reduced their aid assistance and they has still not reached the pre-crisis level after two decades. The US have experienced a massive increase in ODA since 2000, while, before that, their disbursements were still below the level reached at the times of the Saving \& Loans crisis.

Poor countries are also dramatically exposed to the contraction in world remittances, which, other than supporting household consumption and subsistence expenditures, finance investment and stimulate economic growth (Giuliano and Ruiz Arranz 2009; Bettin and Zazzaro 2008). On the whole, remittances are the second source of external finance in developing countries and account for twice the

4 ODA data are drawn from the DAC dataset compiled by OCSE and they are in constant 2000 US dollars (data are deflated using the GDP deflator published in the World Development Indicators). A financial crisis episode is defined following the recent dataset elaborated by Laeven and Valencia (2008, http://www.luclaeven.com/Data.htm) 
inflows of aid. In some countries, remittances account for up to more than 20 percent of output and they are even more important than aid flows. In recent years, remittances inflows grew at double-digit annual rate, being around seven percent of GDP in the average Sub-Saharan Africa country, and more than 12 percent in Latin America. According to the World Bank estimates (Ratha and Mohapatra 2009), the crisis will induce a contraction in remittances flows to the developing world from 5 to 8 percent in 2009. However, remittances would remain more resilient than other sources of capital inflows in developing countries, given that private debt, equity flows and foreign direct investment are expected to decline at a sharper pace.

Figure 2: Crisis and ODA, the past experience
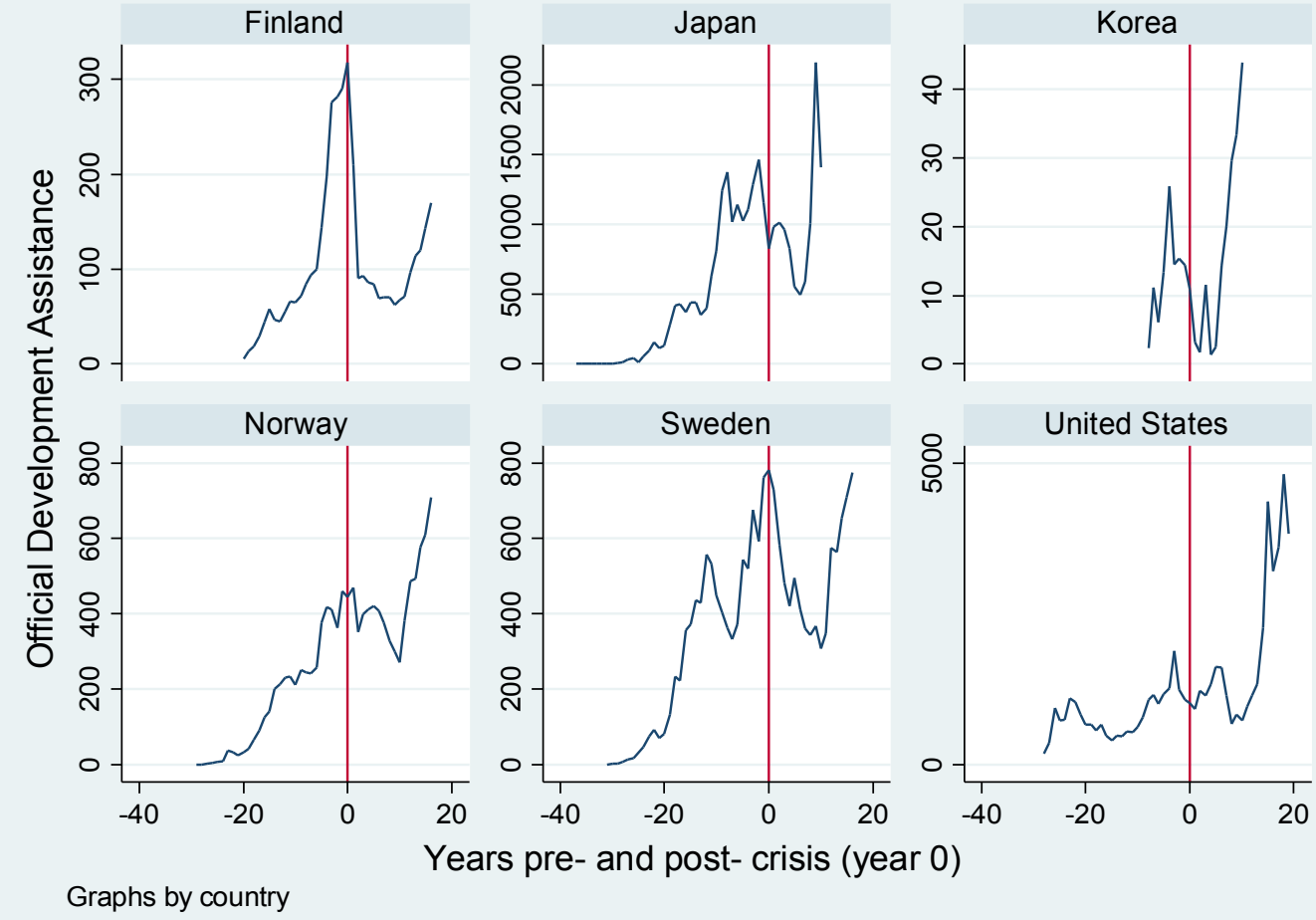

Source: Authors' calculations on OECD, World Bank and Laeven and Valencia (2008) data.

Finally, even if African countries' financial systems are not directly part of the crisis, the extremely large foreign participation in the banking system could have adverse effects on small business finance and entrepreneurship (according to IMF data, in 20 Sub-Saharan African countries the majority of banking assets are foreign-owned). Large multinational banks, in fact, are likely to generate creamskimming effects which penalize small and informationally opaque borrowers (Berger, Klapper and 
Udell 2001; Detragiache, Tressel and Gupta 2008). Moreover, during a financial crisis multinational banks are likely to recur to internal capital markets to rein in their credit supply in order to focus on the home country market, transmitting the home country financial shock to the host country (Peek and Rosengren 1997; Van Rijckeghem and Weder, 2000). Signs of the tightening of credit conditions for bank lending in Ghana and Zambia seem to confirm this hypothesis (de Velte 2009; World Bank 2009b). Financial markets can also be hit by the crisis, since the deterioration in the functioning of US and European interbank markets could force investors to deleverage and reduce their positions in African bond, money and equity markets to raise liquidity. At the moment, in some African countries declines in equity prices, currency depreciations and higher interbank rates are already observable (International Monetary Fund 2009g; World Bank 2009a) ${ }^{5}$.

\section{The Financing Gap and the Responses by the International Financial Institutions}

Thus, because of poor countries' dependence on exports, foreign aid and capital flows, the current recession is likely to have dramatic effects for the world's poorest, especially in Sub-Saharan Africa. The United Nations (2009) stresses how the financial crisis is jeopardizing the achievements of the Millennium Development Goals. Poverty ratios, indicators of hunger, children malnutrition, gender equality, unemployment, they all worsened in 2008. Therefore, developing countries will need additional financial assistance to reverse this recent trend. However, the expected lower levels of aid would not only impede future progresses, but also reverse some of the gains already obtained.

According to a number of different estimates provided by international organizations and by NGOs, developing countries are going to face a financing gap of around USD 140-700 billion, depending on the severity of the crisis, the policy responses and the materializing of different scenarios. The IMF estimates that LIC will have to deal with a balance of payment negative shock of around USD 165 billion, resulting from a fall in exports, FDI, remittances and from adverse price food and fuel changes. Once taken into account the loss in reserves, this shock will result in additional financing needs of about USD 25 billion in 2009. A "bad case" scenario, in which a number of shocks happen

5 The World Bank (2009) estimates that the currency of the average Sub-Saharan African country depreciated by 25 percent against the dollar and that bond spreads widened considerably in 2008-2009, being between 220 and 375 basis point higher than their pre-crisis level in Gabon and Ghana. 
simultaneously, is also simulated and, in this case, total financing needs for LIC will amount to USD 138 billion. Focusing on the whole sample of developing countries, the World Bank estimate that in 2009 many countries (between 59 and 69) will find it difficult to meet external financing needs, estimated at one trillion dollars. While the overall financing gap in 2009 should be between USD 350 billion to USD 635 billion, in Sub-Saharan Africa external financing needs will amount to around USD 150 billion, mainly due to current account deficits, and the financing gap is estimated to be less than USD 100 billion.

The severity of the crisis in LIC is harshened by the national governments' lack of appropriate tools to face the crisis. Apart from few poor countries which were able to accumulate stock of international reserves or to reduce public debt in last years, the majority of developing countries, contrary to the industrialized ones, have limited resources to fund any fiscal stimulus, having no room for countercyclical policies without weakening debt sustainability. In fact, as stressed recently by Reinhart and Reinhart (2009), "[t] he fiscal "space” to implement ambitious stimulus plans in emerging markets is far more limited than that of advanced economies". Moreover, expansionary fiscal policies in developing countries are riskier than in industrialized countries, since for the former group of countries there is a very limited body of analytical and empirical evidence on the effectiveness of the fiscal multiplier and the few available studies point out a smaller effect of fiscal stimulus (Ilzetzki and Végh $2008)^{6}$. Eventually, in developing countries with a recent record of central bank independence, a fiscal expansion could result in financing deficits with money creation, loosing the hard-gained credibility and threatening the pursuit of price stability (Reinhart and Reinhart 2009). A different opinion is expressed in the IMF African Regional Economic Outlook, where it is stated that " $a$ number of subSaharan African countries would have scope for a fiscal expansion [and a] few countries may also have scope for discretionary fiscal stimulus to sustain demand" (International Monetary Fund 2009g: 21). This statement is based on an analysis which assumes that low or moderate risks of debt distress in almost two third of Sub-Saharan African countries can create scope for fiscal expansion. However, as we will discuss in the next Section, the current crisis is severely affecting debt dynamics, so that many countries in the next years can be more vulnerable to fiscal deficits and will have limited scope for expansionary policies, especially if donor assistance will not be scaled up. Anyway, some Sub-Saharan

6 However, also in OECD countries there is no a broad consensus on the magnitude of fiscal multipliers, as emerges also in the recent US debate on the financial crisis (Romer and Romer 2009; Favero and Giavazzi 2009; Mankiw 2009; Spilimbergo, Symansky and Schindler 2009). 
African countries could actually implement discretionary fiscal stimulus to sustain aggregate demand, giving priority to the financing of social safety nets programs. Nevertheless, fiscal policies should consider the specific economic and financial characteristics of Sub-Saharan African countries: limited access to international capital markets and thin domestic financial markets, in fact, could make fiscal policy less effective and might lead to a crowding out of private investment (Berg et al. 2009).

Given the limited room for counter cyclical policies, the role of donors and of the international community in poor countries becomes fundamental. With the unfolding of the crisis, the World Bank and the IMF have developed different strategies aimed at mitigating the effects of the global recession, improving the lending capacity and the pool of resources available to LIC.

The economic crisis and the subsequent higher demand for funds from poor countries has forced the IMF to undertake a substantial revision of its lending instruments to poor countries and to double its borrowing limits, in order to meet the increased needs of LIC, which are severely hit by rising food and oil prices and by the global downturn ${ }^{7}$. According to the IMF, its new initiatives are expected to boost concessional lending to USD 17 billion through 2014, with 8 billion available in the next two years, when they are more needed.

The Exogenous Shock Facility (ESF), originally created to provide financial support to countries facing an exogenous shock, was modified in September 2008 and April 2009 in order to made it faster to access, easier, more flexible to use, and capable of providing more financing. Specifically, a rapid access component allow a country to quickly access to a concessional loan equal to up to a half of its quota, with limited conditionality (the borrower country will only need to commit to appropriate policies to address the shock), while the high access component refer to the 150 per cent of the quota, disbursed under the usual arrangements. Many poor countries have already accessed the modified ESF to avoid to jeopardize their hard-won economic results because of the current crisis. Tanzania, in example, will receive USD 336 million to support its reserves and its balance of payment, under temporary stress because of declining cotton prices, tourism revenues and and foreign direct investment. Cameroon received USD 144 million to finance important investment and health and

7 The IMF provides financial assistance to LIC at concessional rates ( 0.5 per cent) through the Poverty Reduction and Growth Facility (PRGF) and the Exogenous Shock Facility (ESF). For more details on IMF lending activities, see: http://www.imf.org/external/np/exr/facts/howlend.htm (last accessed: September 2009). A detailed review of the IMF financing activities in LICs and of the ongoing reform proposals is in International Monetary Fund (2009i). 
education expenditures, which could have been delayed because of tighter external financing conditions and lower export and fiscal revenues. The IMF approved arrangements under the ESF also for other countries, such as Mozambique and Senegal, to cushion them from the effects of the global economic downturn and to offset the deterioration of their balance of payments.

A more comprehensive and important step was taken on July 2009, when the Executive Board of the IMF approved the proposal to establish a Poverty Reduction and Growth Trust (PRGT), expected to be effective by late 2009, replacing and expanding the previous PRGF-ESF Trust. The new trust include tools to provide flexible medium-term support, as well as instruments designed to meet countries shortterm precautionary and emergency needs. Besides, the focus on growth and poverty alleviation will be strengthened and the IMF will provide exceptional interest relief to countries most severely affected by the global crisis. Specifically, according to an IMF note (International Monetary Fund 2009h), the new structure, "consists of:

- $\quad$ The Extended Credit Facility (ECF). This facility, the successor to the PRGF, will allow the Fund to provide sustained program engagement and financing for countries facing protracted balance of payments difficulties.

- $\quad$ The Standby Credit Facility (SCF). Similar to the Stand-By Arrangement (SBA) widely used by emerging markets, the SCF will provide financial assistance and policy support to LICs with shorter-term or episodic financing needs emanating from a range of sources. It also allows for precautionary use, in cases where there is a potential rather than an actual financing need.

- The Rapid Credit Facility (RCF). This will rapidly provide a limited amount of financing in response to urgent needs, with reduced conditionality particularly appropriate to the transitory nature of the financing need or instances in which policy implementation capacity is constrained".

Similarly, the World Bank is undertaking a number of reforms to increase and speed up its assistance and lending to $\mathrm{LIC}^{8}$. In December 2008, the World Bank made USD 2 billion available to finance spending in basic infrastructure, health and schooling and social safety net programs to protect the poor in the hardest hit countries. In April 2009 it was announced that investment in safety nets and other

$8 \mathrm{~A}$ broad and up-to-date presentation of the World Bank initiatives set up to deal with the financial crisis is available at: http://www.worldbank.org/financialcrisis/bankinitiatives.htm (last accessed: September 2009). 
social protection programs will be triplicated over the next two years. Between July 2008 and June 2009, the World Bank committed USD 58.8 billion to help developing countries struggling with the global crisis: 14 billion ( $+25 \%$ with respect to 2008$)$ consisted of interest-free loans and grants to the world's 79 poorest countries provided through the International Development Association (IDA) (the $56 \%$ of of those funds were channeled to Sub-Saharan African countries). Finally, the World Bank is supporting a "Vulnerability Fund", calling for the developed countries to dedicate the 0.7 percent of their economic stimulus packages to a fund which should provide financial assistance to developing countries suffering for the global downturn which can not afford bailouts and fiscal deficits.

\section{Another Debt Crisis?}

The current financial turmoil and the associated reduction in trade, foreign aid and capital flows might trigger another debt crisis in low income countries. On one side, government revenues are going to decline, especially in oil rich countries, in response to a decline in output, trade and consumption, which reduce the tax base: according to the IMF, central government revenues in LIC are projected to decline from 24.2 percent of GDP in 2007 to 22 percent in 2009. On the other, public spending is rising in order to sustain the overall economy. Subsidies to domestic exporters and to state-owned enterprises, financing schemes to avoid the credit crunch and social spending to mitigate the impact of the crisis on poverty are all contributing to the rise in public expenditures. These two contrasting trends will worsen the fiscal balance.

Increasing financing requirements, coupled with a (possible) decline in international aid is going to push developing countries to finance their deficits borrowing abroad or issuing domestic debt. The rise in external (domestic) lending will increase public debt ratios and will have adverse consequences on the economy. External and domestic lending is becoming more expensive because of the rise in interest rates, which follows the withdraw of foreign investors from poor countries, and the decline in domestic savings. Even countries which were able to access the international financial markets are affected by the liquidity shortage: other than Ghana, also Kenya, Tanzania and Uganda have put on hold their debut Eurobond until market conditions improve. Moreover, the outflows of capital are putting downward

pressures on the exchange rates increasing the cost of foreign currency denominated external (and 
domestic) debt. Subsequently, the rising cost of debt service will worsen the fiscal deficit even further, generating a vicious cycle.

As argued by many commentators, this time many poor countries can cope with the crisis starting from better initial conditions than in the past, thanks to sounder fiscal positions, reduced debt burdens, lower inflation, and comfortable reserve cushions. Nevertheless, those same countries have already been hit by the 2007-2008 food crisis (which is still not over), are still afflicted by widespread poverty, food insecurity, fragility and conflict, and their initial conditions are highly heterogeneous, especially between oil exporter and importer' ${ }^{9}$ With a number of countries with debt ratios close to the 60 (150) percent of GDP (exports) thresholds and at moderate or high risk of debt distress, the projected rise in financing requirements could undermine the positive achievements of debt reduction policies. Debt ratios could quickly bounce back to their pre-debt relief levels, given that the global crisis is adversely affecting both the nominator and the denominator of the debt ratio. Public debt is increasing because of a quantity effect (more lending), but also because of a price effect (in case of foreign currency denominated debt), which works through the depreciation of the exchange rate. By contrast, the denominator, being either exports or GDP, is declining as a result of the global recession and the fall in world trade. In addition, the value of exports has diminished due to the fall in commodity prices, which has worsened the terms of trade in many LIC. The stress tests run under the Debt Sustainability Framework (DSF) contemplate neither multiple adverse external shocks nor one of a such magnitude. Therefore, new ad-hoc simulations and specific policy responses are required.

At the moment, as data are released and projections updated, the decline in exports and GDP is actually worse than expected, exposing many poor countries to a severe shock which could bring them to an unsustainable debt path. That we are still in the midst of the crisis, at least for LIC, has been recently confirmed by the managing director of the IMF, who in a speech delivered in September said that low income countries are being hit by the crisis harder than the IMF thought in March (Dominique StraussKahn 2009).

9 In example, oil and metal producers are the worstly affected by the recent reversal in commodity prices, even if many of them were able to accumulate a fiscal cushion during the boom years which is now alleviating the impact of the crisis (International Monetary Fund 2009a). 
Table 1: Economic growth forecasts for HIPCs pre- and post-crisis

\begin{tabular}{|c|c|c|c|c|c|c|c|c|}
\hline \multirow[t]{2}{*}{ Country } & \multicolumn{4}{|c|}{ April 2009 WEO growth projections } & \multicolumn{4}{|c|}{ Revision with respect to April 2008 WEO } \\
\hline & 2008 & 2009 & 2010 & 2011 & 2008 & 2009 & 2010 & 2011 \\
\hline Afghanistan, Rep. of. & 3.35 & 8.96 & 7.01 & 8.10 & -5.28 & 0.56 & -0.18 & 0.90 \\
\hline Benin & 4.98 & 3.84 & 3.04 & 5.65 & -0.38 & -1.81 & -2.65 & -0.03 \\
\hline Bolivia & 5.92 & 2.20 & 2.90 & 3.30 & 1.22 & -2.80 & -2.20 & -2.70 \\
\hline Burkina Faso & 5.00 & 3.54 & 4.09 & 5.32 & 0.98 & -2.76 & -1.89 & -0.64 \\
\hline Burundi & 4.53 & 3.53 & 3.83 & 3.84 & -1.36 & -2.14 & -2.16 & -2.21 \\
\hline Cameroon & 3.45 & 2.44 & 2.64 & 4.00 & -1.05 & -2.16 & -2.13 & -1.40 \\
\hline Central African Republic & 2.20 & 2.40 & 3.10 & 4.00 & -2.70 & -2.60 & -1.90 & -1.00 \\
\hline Chad & -0.41 & 2.83 & 2.51 & 2.93 & -2.18 & 0.37 & -0.22 & 0.45 \\
\hline Comoros & 0.98 & 0.84 & 1.49 & 2.50 & -0.63 & -2.16 & -3.01 & -2.00 \\
\hline Congo, Democratic Republic of & 6.20 & 2.70 & 5.54 & 7.97 & -2.65 & -8.93 & -6.23 & -1.00 \\
\hline Congo, Republic of & 5.57 & 9.55 & 11.87 & 1.05 & -3.64 & -1.03 & 1.62 & -1.66 \\
\hline Côte d'Ivoire & 2.33 & 3.70 & 4.23 & 4.68 & -0.58 & -1.42 & -1.38 & -1.50 \\
\hline Eritrea & 1.03 & 1.14 & 4.72 & 5.24 & -0.18 & -0.91 & -1.30 & -0.14 \\
\hline Ethiopia & 11.61 & 6.52 & 6.54 & 6.99 & 3.20 & -0.60 & -0.72 & -0.53 \\
\hline Gambia, The & 5.86 & 3.98 & 4.42 & 5.14 & -0.64 & -2.52 & -1.57 & -0.86 \\
\hline Ghana & 7.16 & 4.50 & 4.72 & 16.78 & 0.31 & -2.97 & -2.75 & 9.34 \\
\hline Guinea & 3.96 & 2.55 & 4.14 & 4.69 & -0.92 & -2.66 & -1.34 & -1.02 \\
\hline Guinea-Bissau & 3.33 & 1.90 & 3.10 & 3.76 & 0.10 & -1.22 & -0.25 & -0.18 \\
\hline Guyana & 3.23 & 2.60 & 3.45 & 5.78 & -1.37 & -1.90 & -0.85 & 1.18 \\
\hline Haiti & 1.30 & 1.00 & 2.00 & 3.20 & -2.40 & -3.00 & -2.00 & -0.80 \\
\hline Honduras & 4.00 & 1.50 & 1.90 & 2.20 & -0.85 & -3.10 & -2.60 & -2.20 \\
\hline Kyrgyz Republic & 7.60 & 0.94 & 2.93 & 4.05 & 0.65 & -5.56 & -3.07 & -1.45 \\
\hline Liberia & 7.13 & 4.87 & 7.53 & 10.27 & -2.34 & -5.32 & -5.14 & -2.31 \\
\hline Madagascar & 5.04 & -0.18 & 2.03 & 3.71 & -1.76 & -7.43 & -7.53 & -4.61 \\
\hline Malawi & 9.70 & 6.90 & 6.00 & 5.13 & 2.55 & 0.72 & -1.20 & -2.85 \\
\hline Mali & 4.99 & 3.88 & 4.09 & 4.64 & 0.72 & -1.25 & -1.43 & -1.51 \\
\hline Mauritania & 2.23 & 2.35 & 4.69 & 5.70 & -3.91 & -4.42 & -0.56 & 0.74 \\
\hline Mozambique & 6.18 & 4.30 & 4.00 & 4.50 & -0.85 & -2.69 & -3.05 & -2.00 \\
\hline Nicaragua & 3.00 & 0.50 & 1.00 & 2.00 & -1.00 & -3.70 & -3.70 & -3.00 \\
\hline Niger & 9.52 & 3.02 & 4.51 & 4.46 & 5.08 & -1.50 & -0.49 & -0.74 \\
\hline Rwanda & 11.23 & 5.60 & 5.79 & 5.88 & 5.23 & 0.05 & 0.33 & 0.17 \\
\hline São Tomé and Príncipe & 5.80 & 5.00 & 6.00 & 7.00 & -0.20 & -1.00 & -0.50 & 0.00 \\
\hline Senegal & 2.49 & 3.12 & 3.43 & 4.35 & -2.88 & -2.81 & -2.45 & -1.17 \\
\hline Sierra Leone & 5.52 & 4.49 & 5.30 & 5.97 & -0.96 & -2.03 & -1.02 & 0.00 \\
\hline Sudan & 6.84 & 3.96 & 5.04 & 5.03 & -0.71 & -8.72 & -3.56 & -2.76 \\
\hline Tanzania & 7.46 & 4.97 & 5.66 & 7.17 & -0.31 & -3.03 & -2.35 & -0.83 \\
\hline Togo & 1.10 & 1.69 & 2.15 & 4.05 & -1.90 & -2.31 & -1.85 & 0.05 \\
\hline Uganda & 9.53 & 6.20 & 5.50 & 6.70 & 2.43 & -0.80 & -1.50 & -0.30 \\
\hline Zambia & 6.02 & 4.04 & 4.55 & 5.03 & -0.28 & -2.31 & -1.31 & -0.80 \\
\hline \multicolumn{9}{|c|}{ Country averages } \\
\hline HIPC whole sample & 5.05 & 3.54 & 4.29 & 5.20 & -0.55 & -2.56 & -1.95 & -0.80 \\
\hline Completion Point countries & 6.02 & 3.70 & 4.17 & 5.47 & 0.16 & -2.29 & -1.93 & -0.77 \\
\hline Decision Point countries & 3.28 & 3.83 & 4.83 & 4.97 & -2.23 & -2.51 & -1.72 & -0.73 \\
\hline
\end{tabular}

Source: Authors' calculations based on IMF's World Economic Outlook (April 2008 and April 2009). Somalia is excluded because of lack of data. HIPC classification as of June 2009. 
Figure 3: The effect of the global crisis on HIPCs' economic growth

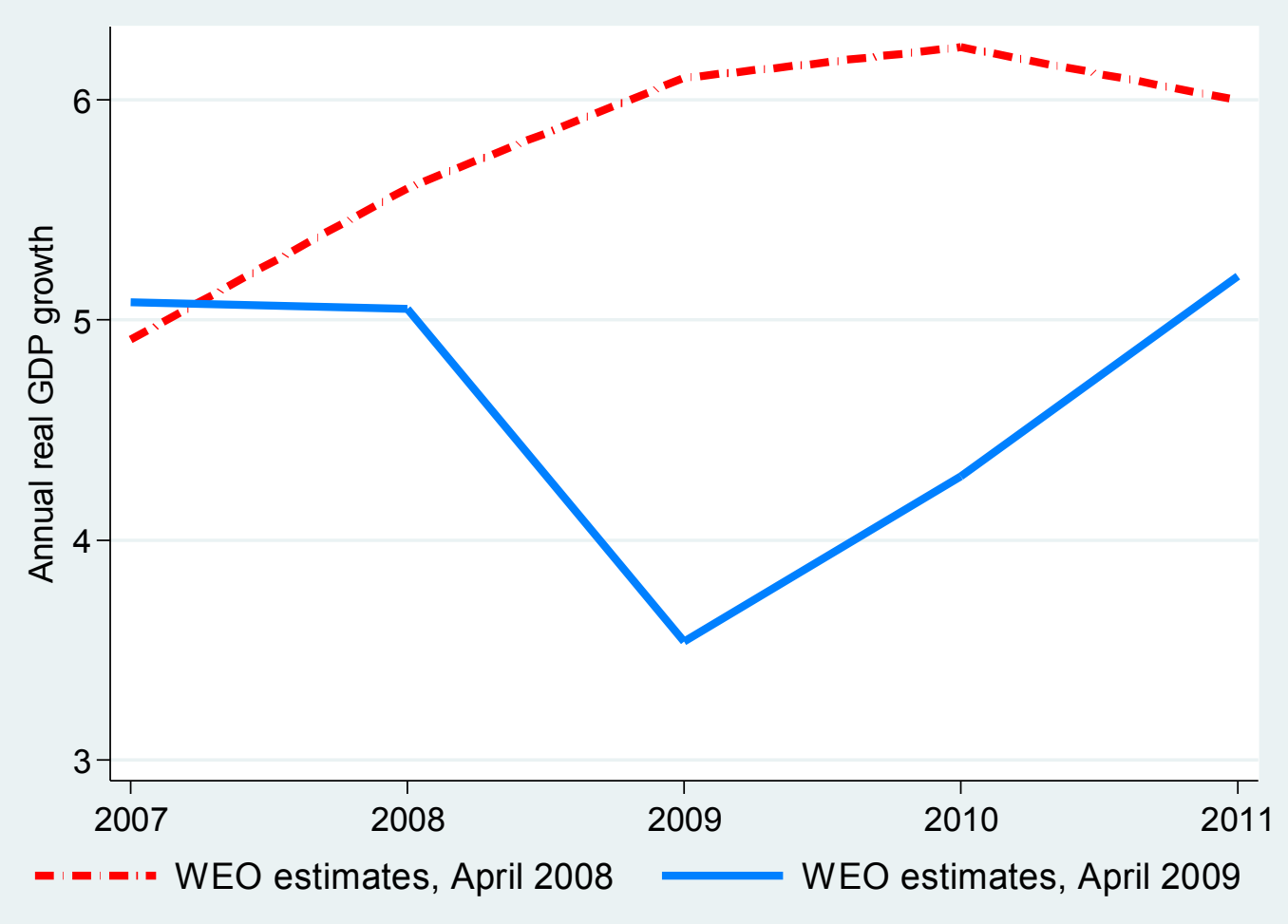

Source: Authors' calculations based on IMF's World Economic Outlook (April 2008 and April 2009). Somalia is excluded because of lack of data. HIPC classification as of June 2009.

In Table 1 we report the data on economic growth for the 39 HIPCs, collected from the IMF World Economic Outlook database. The comparison between the last pre-crisis estimates (International Monetary Fund 2008) and the most recent data and projections, released in the April 2009 World Economic Outlook ${ }^{10}$ (International Monetary Fund 2009f) displays the severity of the crisis and makes it clear that the assumptions of the DSF are generally overly optimistic and that the financial crisis can adversely affect the future evolution of total public debt (Figure 3). For the whole sample of HIPCs, the last estimate project a slowdown of economic growth from 5 in 2008 to 3.5 per cent in 2009 and 4.3 in 2010. By contrast, the 2008 estimates were still consistent with a growth acceleration from 5.6 to 6.2 per cent over 2008-2010. The largest downward revisions are concentrated in 2009, where the average HIPC is projected to grow 2.5 percentage point less than the April 2008 estimated growth rate. The 10 Data are available via the internet at: http://www.imf.org/external/pubs/ft/weo/2009/01/weodata/index.aspx, last accessed: September 2009. 
picture is quite heterogeneous, with differences among Completion and Decision Point countries, as well as between countries themselves. Specifically, if we look at the short term (revision for 2009 and 2010), data suggest that Completion Point countries are better equipped than the others to cope with the crisis. In fact, eight out of the ten most adversely affected by the crisis are Decision or Pre-Decision Point countries (Congo DR, Sudan, Liberia, Senegal, Haiti, Central African Republic, Kyrgyz Republic and Afghanistan), while only Madagascar and Mauritania underwent a sharp downward revision of their growth prospects ${ }^{11}$.

To better gauge the actual impact of the crisis on public debt dynamics, we have compared the debt sustainability analysis (DSA) done after the MDRI with the most recent one, for countries for which a very recent DSA is available. Even if the long-run increase in external debt is generally not worrying, so that the risk of debt distress episodes is often unchanged, the comparison shows a severe deterioration of the debt dynamics in response to the new economic framework. Thus, a further downward revision of the current projections on growth, exports and external assistance will have more alarming effects, possibly triggering perverse debt dynamics. The 2007 DSA for Ghana (International Monetary Fund, 2007a) assumed a real GDP growth rate of 7 percent over the period 2006-2011, and of 5.8 percent thereafter. According to this assumption, after MDRI relief, PPG external debt was equal to 22.3 percent of GDP in 2006 and it would have increased to 27.5 percent in 2012 . By contrast, the most recent DSA (International Monetary Fund 2009b) updates the assumptions setting the output growth below 5 percent in 2009 and 2010. This results in a more explosive debt dynamic, since PPG external debt, revised at 17.3 percent of GDP in 2006, raises to $41.5 \%$ in 2009 and $47.7 \%$ in 2010 . A similar pattern is observable also in other heavily indebted poor countries. In the 2006 DSA for Benin, the assumption on the annual GDP growth rate was set at 5.3 percent over 2006-2011, so that PPG external debt was projected to increase from 12.7 to 16.1 percent of GDP (International Monetary Fund 2007b). By contrast, actual growth rates in 2006-2008 were well below the target and in 2009-2010 output will growth at 3.8 and 3.0 percent, respectively. Thus, according to the most recent DSA (International Monetary Fund 2009c), the Benin debt-to-GDP ratio is estimated to reach 21.4 in 2011 , more than 5 percentage points above the previous projection. In Mozambique, the revision of the

11 According to the International Monetary Fund, the economic outlook for Mauritania, which qualified for the Multilateral Debt Relief Initiative in June 2006, is uncertain because of the sanctions imposed after the 2005 coup and a loosening of fiscal policies (the recent drop in iron ore prices is expected to exert further pressures on international reserves and the government fiscal balance). The downward revision for Madagascar are due to its large dependence on oil, because of its remote location and since it is not an oil producer. 
growth rates implies an increase of the ratio of PPG external debt over GDP from 22.5 in 2008 to 35.1 in 2010, while the pre-crisis estimates where consistent with a debt ratio of 24.7 in 2010 (International Monetary Fund 2007c and 2009d). Similarly, in Senegal the 2007 DSA projected an almost stable debt to GDP ratio under the baseline scenario (from 17.3 in 2006 to 19.6 in 2010), while the most recent DSA updates the 2010 ratio at 26, since in 2006-2008 real output grew annually at a 3.2 percent rate instead that at the projected 4.8 percent (International Monetary Fund 2007d and 2009e).

Hence, given uncertain borrowing policy and with limited liquidity facilities by the IFI to help countries to go through (hopefully) temporary liquidity problems, vulnerable countries are going to face aggravated risks of future debt distress episodes. In addition to that, this scenario could undermine past and current debt relief efforts made by the international community and it could weaken povertyreduction and development policies. Large external debts hinders economic growth in poor countries through the so-called debt overhang effect and the crowding out of investment due to excessive debt service payments (Clements, Bhattacharya and Nguyen 2003; Cordella, Ricci and Ruiz Arranz 2009; Presbitero 2006 and 2008). Moreover, is has been also shown that since 2000 debt relief has been able to achieve some results and free resources from the budget to invest in social infrastructure and poverty-reduction (Presbitero 2009). Therefore, an increase in debt ratios and public debt service might reduce, or even wipe out, the progresses achieved so far, scaling down public investments and pro-poor spending and endangering economic growth.

\section{Concluding remarks}

At the time of writing, many emerging markets have already started growing close to pre-crisis rates, while OECD countries have the resources and the instrument to cope with the current financial crisis and mitigate its effects on displaced workers and the poor. By contrast, the poorest countries are still well below their trend of output growth and lack the appropriate tools to deal with these multiple external shocks. Thus, the poorest people in the poorest countries are the most exposed to the global recession: not only they lack sufficient safety nets for immediate help but also, more importantly, they are going be dramatically affected in the long run by the likely reduction in social spending. A new generation of poor might not benefit from the recent (limited) progress in education and health, with 
severe consequences for individuals, their local communities and for poor countries' growth prospects $^{12}$. The most recent World Bank estimates, for example, suggest that lower growth rates would trap an additional 89 million people into poverty, who sum up to the 130-155 million people pushed into poverty in 2008 because of the soaring food and fuel prices (World Bank 2009b). As stated by the World Bank President, Robert Zoellick, "[t] his is obviously going to have an effect on the Millennium Development Goals, and just to take one example of infant mortality, we estimate that as a result of the sharply lower economic growth rates, that between 200,000 and 400,000 more children a year may die, and that's out of a total of about 1.4 to 2.8 million children that perish each year" (Zoellick 2009). Also the managing director of the International Monetary Fund, Dominique Strauss-Kahn, is "deeply concerned by the potential humanitarian costs of this crisis. [...] starting from what is only a financial crisis, we may at the end have much bigger consequences than only income and growth consequences. For these reasons, low-income countries have to safeguard the funds they have for education and infrastructure, while boosting safety nets to protect the most vulnerable" (The Brooking Institution 2009: 9-10).

To address this potentially tragic situation, the rich world and the IFI should reshape their policy agenda, focusing much more attention and providing more resources and assistance to low-income countries. Some recent steps made by the Multilateral Institutions, such as the "Vulnerability Fund" proposal advanced by the World Bank, the IMF Poverty Reduction and Growth Trust, and the call for a temporary debt moratorium on all official debt of low income countries (UNCTAD 2009) are commendable and encouraging, but are still not enough. As stressed also by Strauss-Kahn, "it's clear that the financing needs are substantial, and they are very urgent. [...] the international community [has] to provide the financing the most vulnerable countries need to preserve their hard-earned gain, and also to prevent a humanitarian crisis. Of course, the primary responsibility to me lies with bilateral donors who must ensure that the aid flows are scaled up, not down" (The Brookings Institution 2009:14). However, the recent G8 summit in L'Aquila in July 2009 confirms the usual "abundance of promises and commitments, without sufficient details and clear mechanisms that would ensure effective implementation" (De Rienzo 2009). The 2005 Gleneagles commitments to double aid to Africa are re-stated, but it is still unclear when the promised additional resources will become

12 Harper et al. (2009) discuss the effect of the crisis on children, stressing their vulnerability and the irreversible long-run effects of child malnutrition, infant mortality and school dropout on future poverty rates, inequality and economic growth. The author report data from a previous study suggesting that a one percent decrease in per capita GDP has been linked to an increase in infant mortality of between 17 and 44 per thousand children born. 
available, especially now that the crisis is severely affecting government budgets.

Even from a self-interested point of view, the rich world should realize that it is in its own interest to help developing countries to cope with the crisis. The threat of another debt crisis, rising political instability and social unrest which generally follow a severe economic downturn (Miguel, Satyanath and and Sergenti 2004), not to mention the increase in transnational criminal activities, should be sound and economically rational arguments to urge rich countries to scale up their involvement in low-income countries.

\section{References}

Arnone M. and Presbitero A.F. (2007). External Debt Sustainability and Domestic Debt in Heavily Indebted Poor Countries, Rivista Internazionale di Scienze Sociali, 2: 187-213.

Arnone M. and Presbitero A.F. (2008). Problemi di coordinamento, incentivi perversi e fondi avvoltoio: i rischi per lo sviluppo dei paesi altamente indebitati, available via the internet at: www.nelmerito.com

Berg A., Funke N., Hajdenberg A., Lledo V., Ossowski R., Schindler M., Spilimbergo A., Tareq S. and Yackovlev I. (2009). Fiscal Policy in Sub-Saharan Africa in Response to the Impact of the Global Crisis, IMF Staff Position Note, No. 09/10, May 2009, Washington, DC.

Berger, A. N., Klapper, L. F., and Udell, G. F. (2001). The ability of banks to lend to informationally opaque small businesses. Journal of Banking \& Finance, 25(12), 2127-2167.

Bettin G. and Zazzaro A. (2008). Remittances and Financial Development: Substitutes or Complements in Economic Growth? Mimeo, available via the internet at: http://papers.ssrn.com/sol3/papers.cfm? abstract id $=1240659$

Clements B.J., Bhattacharya R. and Nguyen T.Q. (2003). External Debt, Public Investment, and 
Growth in Low-Income Countries, IMF Working Paper, No. 03/249.

Cordella T., Ricci L.A. and Ruiz-Arranz M. (2009). Debt Overhang or Debt Irrelevance? IMF Staff Papers, advance online publication, August 4, 2009.

Daseking, C. and Powell R. (1999). From Toronto Terms to the HIPC Initiative - A Brief History of Debt Relief for Low-Income Countries, IMF Working Paper, No. 99/142.

De Renzio P. (2009). The G8 and poor countries: promises, just promises?, available via the internet at: http://www.globaleconomicgovernance.org/blog/2009/07/the-g8-and-poor-countries-promises-justpromises/

de Velte D.W. (2009). Poor countries hit harder than expected by global financial and economic crisis, available via the internet at: http://blogs.odi.org.uk/blogs/main/archive/2009/06/04/global_financial_crisis_poor_developing_countr ies.aspx

Depetris Chauvin N. and Kraay A. (2005). What Has 100 Billion Dollars Worth of Debt Relief Done for Low-Income Countries?, manuscipt, The World Bank, available at: ssrn.com/abstract=818504

Detragiache, E., Tressel, T., and Gupta, P. (2008). Foreign banks in poor countries: Theory and evidence. Journal of Finance, 63(5), 2123-2160.

Easterly W. (2002). How Did Heavily Indebted Poor Countries Become Heavily Indebted? Reviewing Two Decades of Debt Relief, World Development, 30(10):1677-1696.

Evans, H. (1999). Debt Relief for the Poorest Countries: Why Did It Take So Long?, Development Policy Review, 17(3):267-279.

Favero C.A. And Giavazzi F. (2009). How Large Are the Effects of Tax Changes?, CEPR Discussion Paper, No. 7439. 
Frot E. (2009). Aid and the Financial Crisis: Shall we expect Development Aid to Fall?, mimeo, University of Stockholm.

Giuliano, P. and Ruiz-Arranz, M. (2009). Remittances, Financial Development, and Growth, Journal of Development Economics, forthcoming.

Harper C., Jones N., McKay A. and Espey J. (2009). Children in times of economic crisis: Past lessons, future policies, ODI Background Note, March 2009, Overseas Development Institute.

Hostland D. (2009). Low-Income Countries' Access to Private Debt Markets, World Bank Policy Research Working Paper, No. 4289.

Ilzetzki E. and Végh C.A. (2008). Procyclical Fiscal Policy in Developing Countries: Truth or Fiction?, NBER Working Paper, No. 14191.

International Monetary Fund (2007a). Ghana: 2007 Article IV Consultation, IMF Country Report No. 07/210, June 2007, Washington, DC.

International Monetary Fund (2007b). Benin: 2007 Article IV Consultation, IMF Country Report No. 07/6, January 2007, Washington, DC.

International Monetary Fund (2007c). Mozambique: 2007 Article IV Consultation, IMF Country Report No. 07/262, July 2007, Washington, DC.

International Monetary Fund (2007d). Senegal: 2006 Article IV Consultation, IMF Country Report No. 07/335, September 2007, Washington, DC.

International Monetary Fund (2008). World Economic Outlook April 2008, International Monetary Fund, Washington, DC. 
International Monetary Fund (2009a). The Implication of the Global Financial Crisis for Low-Income Countries, International Monetary Fund, Washington, DC.

International Monetary Fund (2009b). Ghana: 2009 Article IV Consultation, IMF Country Report No. 09/256, August 2009, Washington, DC.

International Monetary Fund (2009c). Benin: Staff Report, IMF Country Report, No. 09/252, August 2009, Washington, DC.

International Monetary Fund (2009d). Mozambique: 2009 Article IV Consultation, IMF Country Report No. 09/227, July 2009, Washington, DC.

International Monetary Fund (2009e). Senegal: Staff Report, IMF Country Report No. 09/205, July 2009, Washington, DC.

International Monetary Fund (2009f). World Economic Outlook April 2009, International Monetary Fund, Washington, DC.

International Monetary Fund (2009g). Regional Economic Outlook: Sub-Saharan Africa, April 2009, International Monetary Fund, Washington, DC.

International Monetary Fund (2009h). IMF Reforms Financial Facilities for Low-Income Countries, Public Information Notice No. 09/94, July 29, 2009, Washington, DC.

International Monetary Fund (2009i). The Fund's Facilities and Financing Framework for Low-Income Countries, February 25, 2009, Washington, DC.

Jubilee Debt Campaign (2009). A New Debt Crisis?, March 2009, London.

Kose M.A., Prasad, E.S., Rogoff K. and Wei S., 2009, Financial Globalization: A Reappraisal, IMF Staff Papers, 56(1):8-62. 
Laeven L. and Valencia F. (2008). Systemic Banking Crises: A New Database, IMF Working Paper, No. $08 / 224$.

Mendoza R.U., Jones R. and Vergara G. (2009). Will the global financial crisis lead to lower foreign aid? A first look at United States ODA, Fordham Economics Discussion Paper Series, No. dp2009-01.

Mankiw G. (2009). Are fiscal multipliers now big or small?, Available via the internet at http://gregmankiw.blogspot.com/2009/03/are-fiscal-multipliers-now-big-or-small.html

Miguel E., Satyanath S. and Sergenti E. (2004). Economic Shocks and Civil Conflict: An Instrumental Variables Approach, Journal of Political Economy, 112(4): 725-53.

Mold, A., Paulo, S. and Prizzon, A. (2009). Taking Stock of the Credit Crunch: Implications for Development Finance and Global Governance, OECD Development Center Working Paper No. 277.

Peek, J. and Rosengren, E.S. (1997). The international transmission of financial shocks: The case of Japan. American Economic Review, 87, 495-505.

Prasad E., Rajan R.G. and Subramanian A. (2006). Patterns on International Capital Flows and Their Implications for Economic Development, Proceedings, Federal Reserve Bank of Kansas City, 119-158

Presbitero A.F. (2006). The Debt-Growth Nexus: a Dynamic Panel Data Estimation, Rivista Italiana degli Economisti 3(4):417-462.

Presbitero A.F. (2008). The Debt-Growth Nexus in Poor Countries: A Reassessment, Economics: The Open-Access, Open-Assessment E-Journal, 2(30).

Presbitero A.F. (2009). Debt-Relief Effectiveness and Institution-Building, Development Policy Review, 27(5): 529-559. 
Ratha D. and Mohapatra S. (2009). Revised Outlook for Remittance Flows 2009-2011: Remittances expected to fall by 5 to 8 percent in 2009, Migration and Development Brief, No. 9, The World Bank.

Reinhart C.M. and Reinhart V. (2009). Is there scope for fiscal stimulus for debt-intolerant countries?, available via the internet at: http://www.voxeu.org/index.php?q=node/3893

Romer C.D. and Romer D.H. (2009). The Macroeconomic Effects of Tax Changes: Estimates Based on a New Measure of Fiscal Shocks, American Economic Review, forthcoming.

Spilimbergo A., Symansky S. and Schindler M. (2009). Fiscal Multipliers, IMF Staff Position Note, No. 09/11, May 2009, Washington, DC.

Strauss-Kahn D. (2009). The Global Financial Crisis and Low-Income Countries - Domestic and International Policy Responses, Speech delivered at the Center for Global Development, September 17, 2009, available via the internet at: http://www.imf.org/external/np/speeches/2009/091709.htm

Teunissen, J.J. and Akkerman A. (2004). Introduction, in "HIPC Debt Relief: Myths and Reality", The Hague: Forum on Debt and Development (FONDAD).

The Brookings Institution. (2009). The Impact of the Financial Crisis on Low-Income Countries, March 3, 2009, Washington DC, available via the internet at: http://www.brookings.edu/ /media/Files/events/2009/0303 imf/20090303 imf.pdf

The Economist. (2009) The toxins trickle downward, March 13, 2009.

UNCTAD (2009). Trade and Development Report, Geneva.

United Nations (2009). The Millennium Development Goals Report 2009, New York.

Van Rijckeghem, C. and Weder, B. (2000). Spillovers through banking centers: A panel data analysis, IMF Working Paper No. 88, Washington, DC. 
World Bank (2009a). Global Development Finance 2009, Washington, DC.

World Bank (2009b). Protecting Progress: The Challenge Facing Low-Income Countries in the Global Recession, Background paper prepared by World Bank Group staff for the G-20 Leaders' Meeting, Pittsburgh, USA, September 24-25, 2009.

Zoellick R.B. (2009). Roundtable with Media, G7 Finance Minister Meeting, Rome, 13 February 2009, available via the internet at: http://go.worldbank.org/0YHVV64T90 